\title{
IMPROVING PLASTIC WASTE SKILLS IN THE UPCYCLED PROGRAM
}

\author{
Euis WIDIATI \\ Faculty of Economics and Business, Sahid University, Indonesia \\ euis_widiati@usahid.ac.id
}

\begin{abstract}
The amount of plastic waste production is increasing due to many foods and beverages packed using plastic. Plastic waste is classified as a difficult to decompose material, so it is necessary to process plastic waste skills to have good value and benefits. This kind of upcycled program is expected to reduce plastic waste, and its processed products can be beneficial for improving the community's economy. This program is upcycled given to children at Yayasan Langkah Kecil Indonesia, Banten. This training assistance aims to realize the community's active role in processing waste into beneficial results and selling value to be used as an entrepreneurial provision. In addition, handicraft skills by making plastic works are expected to improve the understanding and mastery of participants. The implementation method used in this training is participatory, namely the involvement of members in making decisions, including planning. The training activity is grouped by the age of participants, ranging from elementary school-age children to middle school. The facilitator will accompany during the training process, from giving instructions and directions to working tutorials. Upcycled activities in this activity focus on plastic waste, especially plastic packaging beverage waste. Plastic beverage bottles will be processed into another product that provides benefits and good value, such as a pencil case or a ballpoint stand.
\end{abstract}

Keywords: Plastic Waste, Upcycled, Reduce, Reuse

\section{BACKGROUND}

Garbage is the rest of daily human activities and or natural processes in the form of solid, the definition as stated in Law No. 18 of 2008 on waste management. The waste problem has become a national problem in Indonesia because it is produced every day and throughout the year. The World Bank, in a report in September 2019, released data on global waste production. The international financial institution claims that in 2016 there were 2.01 billion tons of garbage piled up in the world.

For developed countries, waste is already an essential part of an industry of management and reuse. But not so with developing countries, because it still has difficulty in handling the garbage problem. The Ministry of Environment and Forestry explained that by 2020 the total national waste production had reached 67.8 million tons. It is indicated that about 185,753 tons of waste are produced daily by 270 million people, or each resident produces about 0.68 kilograms of waste per day (Setiawan, 2021).

Based on the National Waste Management Information System (Kementerian Lingkungan Hidup dan Kehutanan, 2020), 17\% of the plastic waste composition is ranked third as a contributor to waste in Indonesia. The primary source of waste is $37.7 \%$ of the household industry. Currently, the activity of sorting waste is still not cultivated in Indonesian society. Therefore, the central government also strengthens local governments' commitment and active role in reducing waste management, including making waste as economic raw materials.

Exporting plastic waste is not a viable, sustainable long-term solution for our planet. This study suggests that shipping plastic waste is part of the problem: moving high volumes of consumed plastic waste outside of a country (typically from high-income to low-income countries). Encourages consumption of plastics in artificially "cleaner" countries and should not be enabled without guarantees that plastic waste can be efficiently recycled without environmental damage (Barnes, 2019)despite obvious contributions to the global problem of plastics pollution. This paper attempts to provide an explanation for this phenomenon based on construal level theory, positing that plastic waste is a problem that is perceived as "out of sight and out of mind" for consumers in high plastic consumption (typically high income.

One of the efforts to solve the waste is to do waste management that can be done with the principle of $3 \mathrm{R}$ (reduce, reuse, and recycle). The $3 \mathrm{R}$ principle is the main principle of managing waste from the source through various measures to minimize trash dumped into landfills. The primary step is the removal from the start. According to Environmental Services Program, the key to the success of the cleaning and waste management program lies in the selection. Without the piece of waste, processing becomes problematic, expensive, and high risk of polluting the environment and endangering health (Sulistiyorini et al., 2015).

The recycled quality and the efficiency of mechanical recycling have a significant influence on its environmental performance, which influences its comparison with chemical recycling (Jeswani et al., 2021) creating significant amounts of waste. It is important that such waste be managed appropriately in line with circulareconomy principles. One option for managing plastic waste is chemical recycling via pyrolysis, which can convert it back into chemical feedstock that can then be used to manufacture virgin-quality polymers. However, given that this is an emerging technology not yet used widely in practice, it is not clear if pyrolysis of waste plastics is sustainable on a life cycle basis and how it compares to other plastics waste management options as well as to the production of virgin plastics. Therefore, this study uses life cycle assessment (LCA. So that recycling activities become important in ecological improvement efforts. In addition, it is also essential to involve the community 
in conducting environmentally conscious activities and getting used to doing garbage sorting to facilitate the recycling process.

Primary recycling is recycling plastic waste into products with a quality equivalent to the original product. Recycling this way can be done on clean plastic waste, not contaminated with other materials, and consists of one type of plastic only. Secondary recycling is recycling that produces products similar to the original product but with the quality below it. Tertiary recycling is recycling plastic waste into chemicals or fuel. Quarter recycling is the process of getting the energy contained in plastic waste (Surono, 2013)industry and population. On one hand, the invention of plastic has a remarkable positive impact, because it has many advantages compared to other materials. But on the other hand, the plastic waste has negative impact that too worried, so its solutions need to be looked for. One of the alternative handling of plastic waste that currently extensively researched and developed is converting plastic waste into fuel. Converting plastic waste into fuel oil can be done with cracking process. There are three kinds of process that is hydro cracking, thermal cracking and catalytic cracking. Fuel oil produced from the cracking of plastic waste depending on the plastic type, cracking process used, catalyst type, pyrolisis temperature and condenser temperature. Kata kunci: plastic, fuel, hydrocracking, thermal cracking, catalytic cracking PENDAHULUAN Sejak ditemukan pertama kali pada tahun 1907, penggunaan plastik dan barang-barang berbahan dasar plastik semakin meningkat. Peningkatan penggunaan plastik ini merupakan konsekuensi dari berkembangnya teknologi, industri dan juga jumlah populasi penduduk. Di Indonesia, kebutuhan plastik terus meningkat hingga mengalami kenaikan rata-rata 200 ton per tahun. Tahun 2002, tercatat 1,9 juta ton, di tahun 2003 naik menjadi 2,1 juta ton, selanjutnya tahun 2004 naik lagi menjadi 2,3 juta ton per tahun. Di tahun 2010, 2,4 juta ton, dan pada tahun 2011, sudah meningkat menjadi 2,6 juta ton. Akibat dari peningkatan penggunaan plastik ini adalah bertambah pula sampah plastik. Berdasarkan asumsi Kementerian Lingkungan Hidup (KLH.

According to (Restuningdiah et al., 2021), literacy in inorganic waste management is also needed to manage organic waste. Independent waste management at the household level will significantly help reduce the waste problem. Organic waste can be processed into compost, while inorganic waste needs to be sorted. For this type of inorganic waste, one them is plastic waste which requires a waste selection process. Plastic waste has many advantages if it can be used as a recycled product. Therefore, the main activity in this program is processing used plastic to pencil cases and stand ballpoint (Sholihah et al., 2019).

Reduce plastic waste by recycling plastic waste. It is necessary to know the types of plastic in the market. According to the American Society of Plastic Industry, a resin coding system has been established for recycled plastics. Polyethylene (PE) is the main category of plastic waste trade, which has the most significant recycling value and sustainable development value among the types of plastic waste (Zhao et al., 2021).

In the process of waste management, one of them is the concept of reuse. The reuse concept is applied by cleaning plastic waste before being processed into crafts (Yunik'ati et al., 2019). After cleaning, the plastic is then sewn into various skills with exciting shapes and multiple sizes. In this upcycled program activity, they will make crafts made from plastic drinking bottles, which will be converted into pencil cases or stand ballpoints.

The success of the program "no plastic" needs the participation of the community at large. Efforts to invite community participation in managing the environment in which they live can increase public awareness, significantly impacting aspects of environmental hygiene with an active role in waste processing. In addition, a clean and healthy environment will strengthen community initiatives in maintaining, maintaining, and improving ecological functions. Other benefits with the ability of the community to contribute to waste management will also depend heavily on the income of the community, especially the foster children in the partners of Yayasan Langkah Kecil Indonesia.

Yayasan Langkah Kecil Indonesia opens participation with partners to develop children assisted by the foundation. In this devotional activity, empowerment activities are carried out so that the foundation's children have skills and can increase income for their families. The skills taught to these children are by processing plastic waste or known as upcycled programs.

Efforts to improve a better and prosperous life are with education to hope that their children can finish school to secondary school. But another important issue is how to put people who do not have the opportunity to be highly educated can be empowered so that they have the skills to increase their family income.

Through community service programs in mentoring training skills to process plastic waste, one way that can be done is through community service programs in mentoring training skills. The following things behind the service program plan in the form of skills training assistance are as follows:

1. Plastic is a material that is difficult to decompose, so that if the recycling process is not done by making the material appropriate, then the plastic will only end up as waste in the environment

2. Handicrafts by making plastic works are expected to improve understanding and skills

3. The realization of the community's active role in processing waste into beneficial results and selling value can be used as an entrepreneurial provision.

The concept of community development is a community organization, which means organizing the 
community as a system to serve its citizens in changing settings. Thus, the essence of understanding is to encourage citizens to organize themselves to carry out activities to achieve them (Wibhawa et al., 2010). According to (Noor, 2011), the utilization of research results to develop and apply science and technology in community activities is directed to improve the community's welfare. In action, the utilization is adjusted to the needs and conditions of the community where the community is organized.

There are two types of participation, according to Midgley: Authentic Participation and Pseudo Participation. There are three criteria in authentic participation: citizen contributions to the program, citizen involvement in decision-making, and the acceptance of program benefits evenly. If one of the three criteria cannot be met, participation is Pseudo Participation or pseudo participation.

\section{METHODS}

Based on the analysis of the situation faced in the field, there needs to be a more creative program in utilizing and processing plastic waste into a handicraft or a specific product that can later be used as a job for the community. With a more creative program in utilizing plastic waste into a high-value creation in the community, the community's economy will be increasing because used plastic processed products are worth higher than just selling used plastic to intermediaries.

The first step taken in this community partnership program needs analysis to provide solutions to the problem. The service in cooperation with partners identifies several things that must be done immediately to realize this community partnership program, determine the target group to be built, develop training scenarios, and identify the equipment needed during this community partnership program. The necessary inclusive and sustainable plastic waste management can be achieved when both personal behavioral and social, institutional changes occur gradually and simultaneously (as shown in Figure 1) (Raja et al., 2021).

Based on coordination with Yayasan Langkah

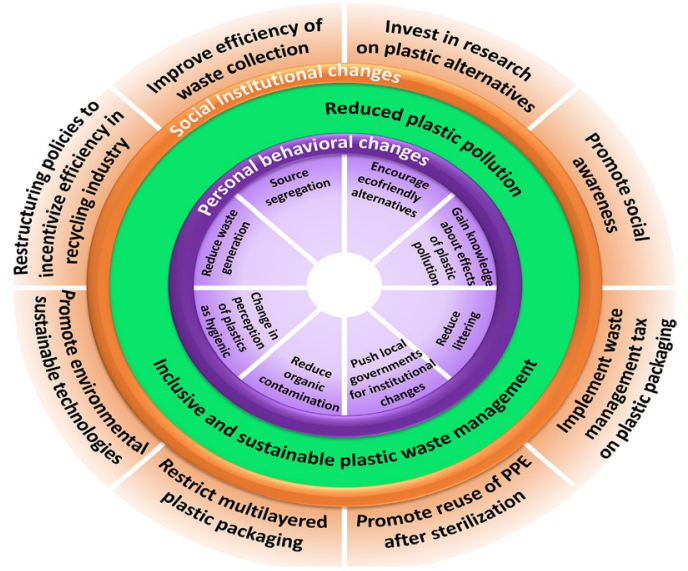

Figure 1. Ilustration depicting an approach to reduce plastic pollution and to bring more inclusive and sustainable plastic waste management
Kecil Indonesia partners, the number of participants involved is 40 people, and 20 volunteers as escorts. To achieve the objectives of this community service of implementation are carried out, namely:

1. Coordination Team

Coordination activities with the team aim to prepare materials and all the needs to socialize with the foundation, so that very familiar environment in a sustainable and thoroughly needed an exciting media and considered profitable for the community through upcycled programs of plastic waste.

2. Coordination with Partner

The team members and I coordinate directly with Yayasan Langkah Kecil Indonesia. For the program to run well as planned, the participants can feel the results now.

3. Program Planning

There are several stages in program planning, namely:

a) Preparation of facilities and infrastructure

b) Socialization of upcycled programs

c) Training assistance skills to process plastic drinking bottle waste

4. Implementation of Activities

In training assistance activities, processing plastic waste from used beverage bottles is included in the primary recycling type. The stage of preparation that needs to be done is to choose the kind of plastic waste commodity to be processed. After separating the types of plastic packaging to be recycled in bottles and glasses, it is necessary to prepare equipment for the recycling process. Table 1 of equipment needs used.

5. Program Evaluation

This evaluation is carried out during implementation. We evaluate in the form of providing feedback and suggestions for improvements to the processes that have been carried out. Efforts to reduce the use of plastic must deal with the socio-cultural aspects of society that have not been able to switch from plastic and environmental awareness, which must continue to be optimized. The role of the government is essential to educate the public. They can sort waste and reduce littering behaviour, increase the capacity of the Waste Bank, manage scavengers and collectors, build cooperation between the two parties, and carry out the final processing to waste that Waste Bank can no longer process. And collectors (Septiani et al., 2019).

Table 1 Materials and Tools Used

\begin{tabular}{ll} 
No $\begin{array}{l}\text { The Name of Materials and } \\
\text { Tools }\end{array}$ & $\begin{array}{c}\text { The figure of Materials } \\
\text { and Tools }\end{array}$ \\
\hline 1 & $\begin{array}{l}\text { Scissors, Glue Gun, Glue } \\
\text { UHU. }\end{array}$ \\
2 Accessories (ribbon, \\
embroidery)
\end{tabular}




\section{RESULT AND DISCUSSION}

In collaboration with Yayasan Langkah Kecil Indonesia, Banten area, the plastic waste processing assistance system involves students and accompanying brothers who are volunteers of activities. Training efforts to process plastic waste into other goods that have functional value and benefits reduce the number of piles of plastic waste and improve the community's economic chain. The participation of outside parties in the waste processing assistance program with Yayasan Langkah Kecil Indonesia has been going well. The volunteers who act as the companion brother have helped the training process, especially in accompanying elementary schoolage children.

In the early stages, the facilitator will briefly explain the purpose of the activity and its benefits. The facilitator will explain one by one the tools and materials that will be used so that trainees can recognize them directly. Furthermore, there will be a demo of how to process plastic waste by illustrating examples of results that have been created as visualization materials for children when practising them. The program that aims to develop the creative economy of its people is expected to succeed in creating a creative industry for the students of Yayasan Langkah Kecil Indonesia. The results achieved in this program are the procurement of supporting equipment activities, training on the utilization of plastic waste or used goods, and training in processing plastic bottles into a pencil case and stand ballpoint.

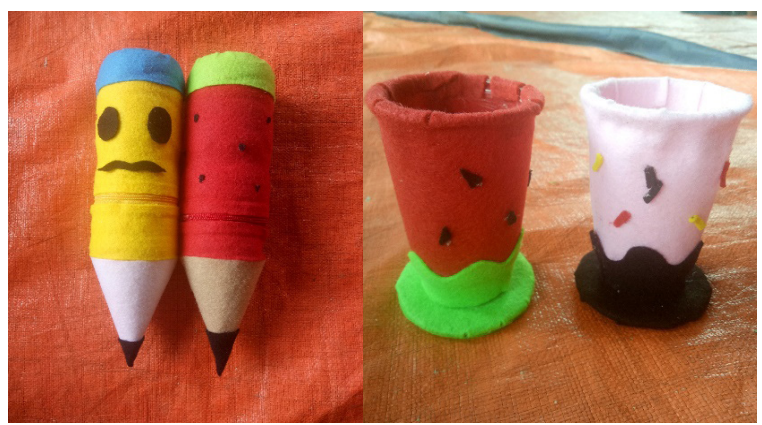

Figure 2. Stand Ballpoint and Pencil Case

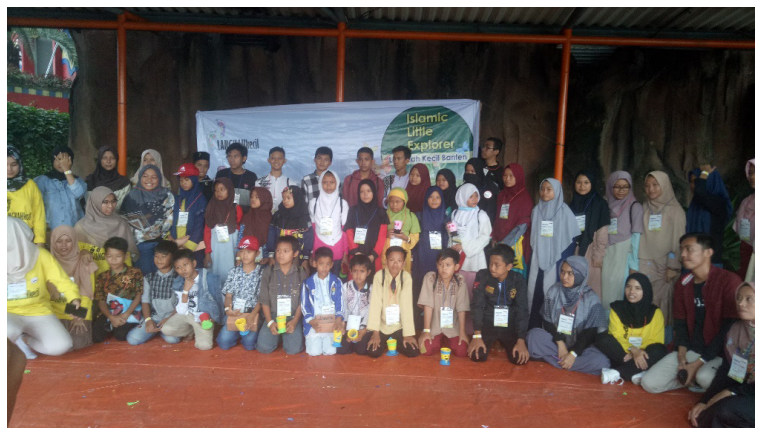

Figure 3. Photo with Participants from Yayasan Langkah Kecil Indonesia

\section{CONCLUSION}

The plastic waste processing assistance system in collaboration with the Yayasan Langkah Kecil Indonesia Banten area involves students and accompanying brothers who are volunteers of activities. Training efforts to process plastic waste into other goods that have good value and benefits reduce the number of piles of plastic waste and improve the community's economic chain. The participation of outside parties in the waste processing assistance program with Yayasan Langkah Kecil Indonesia has been going well. The volunteers who act as the companion brother have helped the training process, especially in accompanying elementary schoolage children.

The results achieved in this skill training activity are understanding the importance of maintaining the environment, sorting waste, and processing plastic waste into practical value. At the end of the purpose of this activity is microeconomic improvement and support for environmental hygiene. Hopefully, gradually people in Indonesia have the skills and independence in managing waste at the individual level to move communally to support a better quality of life.

Community participation as an external party needs improvement to realize a healthy and clean residential environment to utilize existing plastic waste into valuable goods. For a long-term journey, we need to involve any part of the person.

\section{ACKNOWLEDGMENT}

This Community Service Program is the output of internal grants and is financed by the Institute of Research and Community Service (LPPM) of Sahid University Jakarta. Thank you to Prof. Giyatmi as Head of LPPM Sahid University. Thank you to dr Nadia Putri, the Head of Yayasan Langkah Kecil Indonesia, who gives us a chance.

\section{REFERENCES}

Barnes, S. J. (2019). Out of sight, out of mind: Plastic waste exports, psychological distance and consumer plastic purchasing. Global Environmental Change, 58, 1-9. https://oi.org/10.1016/j.gloenvcha.2019.101943

Jeswani, H., Krüger, C., Russ, M., Horlacher, M., Antony, F., Hann, S., \& Azapagic, A. (2021). Life cycle environmental impacts of chemical recycling via pyrolysis of mixed plastic waste in comparison with mechanical recycling and energy recovery. Science of the Total Environment, 769, 1-15. https://doi. org/10.1016/j.scitotenv.2020.144483

Kementerian Lingkungan Hidup dan Kehutanan. (2020). Grafik Komposisi Sampah. https://sipsn.menlhk. go.id/sipsn/

Noor, I. H. (2011). Pemanfaatan Ilmu Pengetahuan dan Teknologi Dalam Kegiatan Pengabdian Masyarakat di Perguruan Tinggi. Jurnal Pendidikan Dan Kebudayaan, 17(3), 306-315. https://doi. org/10.24832/jpnk.v17i3.27

Raja,K., Bhakta,H.,Prakash,V., Samal,B., \&Bhattacharya, J. (2021). Science of the Total Environment 
Challenges and strategies for effective plastic waste management during and post COVID-19 pandemic. Science of the Total Environment, 750, 141514. https://doi.org/10.1016/j.scitotenv.2020.141514

Restuningdiah, N., Nagari, P. M., Jati, F. D., \& Aulia Azzardina. (2021). Literasi Bank Sampah dan Asuransi Sampah Sebagai Upaya Peningkatan Kesejahteraan Masyarakat. 4(36), 144-152. https:// doi.org/10.33474/jipemas.v4i1.9140

Septiani, B. A., Arianie, D. M., Fide, V., Andi, A., Saptuti, I., \& Kawuryan, S. (2019). Pengelolaan Sampah Plastik di Salatiga : Praktik dan Tantangan. Jurnal Ilmu Lingkungan, 17(1), 90-99. https://doi. org/10.14710/jil.17.1.90-99

Setiawan, A. (2021). Membenahi Tata Kelola Sampah Nasional. Portal Informasi Indonesi. https:// indonesia.go.id/kategori/indonesia-dalamangka/2533/membenahi-tata-kelola-sampahnasional

Sholihah, F. A., Normaladewi, A., \& Laksono, P. T. (2019). Pengolahan Plastik Bekas Menjadi Bantal Hias di Desa Ngempit Kecamatan Kraton Kabupaten
Pasuruan. Jurnal Inovasi Hasil Pengabdian Masyarakat, 2(1), 9-17.

Sulistiyorini, N. R., Darwis, R. S., \& Gutama, A. S. (2015). Partisipasi Masyarakat Dalam Pengelolaan Sampah Di Lingkungan Margaluyu Kelurahan Cicurug. Share Social Work Journal, 5(1), 75-85.

Surono, U. B. (2013). Berbagai Metode Konversi Sampah Plastik menjadi Bahan Bakar Minyak. Jurnal Teknik, 3(April 2013), 32-40.

Wibhawa, B., Raharjo, S. T., \& Budiarti, M. (2010). Dasardasar pekerjaan sosial: pengantar profesi pekerjaan sosial. Widya Padjadjaran.

Yunik'ati, Imam, R. M., Hariyadi, F., \& Choirotin, I. (2019). Sadar pilah sampah dengan konsep 4R (Reduce, Reuse, Recycle, Replace ) di desa Gedongarum, Kanor, Bojonegoro. Jurnal Inovasi Hasil Pengabdian Masyarakat, 2(2), 81-87.

Zhao, C., Liu, M., Du, H., \& Gong, Y. (2021). The evolutionary trend and impact of global plastic waste trade network. Sustainability (Switzerland), 13(7), 1-19. https://doi.org/10.3390/su13073662 